\title{
Popular Urbanization: Conceptualizing urbanization processes beyond informality
}

Monika Streule, Ozan Karaman, Lindsay Sawyer, and Christian Schmid

Monika Streule

ETH Zürich, Department of Architecture

Stefano-Franscini-Platz 5

ETH Hönggerberg

$\mathrm{CH}-8093$ Zurich, Switzerland

streule@arch.ethz.ch

Ozan Karaman

Laboratoire Techniques, Territoires et Sociétés (LATTS)

Université Gustave Eiffel

Centre national de la recherche scientifique (CNRS)

Ecole des Ponts ParisTech (ENPC)

Marne-la-Vallée, France

ozan.karaman@enpc.fr

Lindsay Sawyer

Department of Urban Studies and Planning

The University of Sheffield

Western Bank

Sheffield, S10 2TN, UK

sawyer@sheffield.ac.uk

Christian Schmid

ETH Zürich, Department of Architecture

Stefano-Franscini-Platz 5

ETH Hönggerberg

$\mathrm{CH}-8093$ Zurich, Switzerland

schmid@arch.ethz.ch

\section{Acknowledgements}

This article is a result of the collaborative research project 'Patterns and Pathways of Planetary Urbanization in Comparative Perspective' conducted at the ETH Future Cities Laboratory 
Singapore (FCL) and the Chair of Sociology, Department of Architecture at ETH Zürich. We thank all our colleagues from the Future Cities Laboratory for their support, advice and inspiration. We express our special thanks to the project team members Naomi Hanakata, Pascal Kallenberger, Anne Kockelkorn, Kit Ping Wong and Rob Sullivan who contributed substantially to the development of the concepts of urbanization presented here. We would like to thank Jennifer Robinson and AbdouMaliq Simone for insightful and valuable comments. Many thanks as well to all the interlocutors and researchers in Mexico City, Lagos and Istanbul who shared their knowledge with us. Furthermore, we thank Fabio Duarte and Nicole Weiss for revising the translations from Spanish and French into English, the IJURR handling editor and three anonymous referees for their careful reading and constructive suggestions. All errors and omissions remain the responsibility of the authors.

\section{Abstract}

This article introduces the concept of popular urbanization to describe a specific urbanization process based on collective initiatives, self-organization and the activities of inhabitants. We understand popular urbanization as an urban strategy through which an urban territory is produced, transformed and appropriated by the people. This concept results from a theoretically guided and empirically grounded comparison of Mexico City, Istanbul and Lagos. Based on postcolonial critiques of urban theory and on the epistemologies of planetary urbanization, we bring urbanization processes in these urban regions into conversation with each other through a multidimensional theoretical framework inspired by Henri Lefebvre focusing on material interaction, territorial regulation, and everyday experience. In this way, popular urbanization emerged as a distinct urbanization process, which we identified in all three contexts. While this process is often subsumed under the broader concept of 'urban informality', we suggest that it may be helpful to distinguish popular urbanization as primarily led by the people, while commodification and state agencies play minor roles. As popular urbanization unfolds in diverse ways dependent upon the wider urban context, specific political constellations and actions, it results in a variety of spatial outcomes and temporal trajectories. This is therefore a revisable and open concept. In proposing the concept of popular urbanization for further examination, we seek to contribute to the collective development of a decentered vocabulary of urbanization.

\section{Keywords}

urbanization processes, comparative urban research, postcolonial urbanism, planetary urbanization, popular urbanization, urban informality, Istanbul, Lagos, Mexico City 


\section{Introduction}

This article introduces the concept of popular urbanization generated through a theoretically guided and empirically grounded comparison of Mexico City, Lagos and Istanbul. We propose this concept as a tool for the analysis of a specific urbanization process based on collective initiatives, various forms of self-organization and the engagement and labor of mostly poor or low-income people that has become an important part of everyday realities in many cities around the globe. Popular urbanization has been subsumed so far under concepts such as 'urban informality', 'incremental urbanism' or 'peripheral urbanization'. Fully acknowledging the relevance of these broader concepts, our effort goes in a complementary direction, identifying specific urban processes across different geographical and historical contexts. More precise concepts are needed to put different urban outcomes into conversation with others in order to extend the ways in which we can understand and talk about the nature of the urban, in both its multiplicity and complexity (Robinson, 2016: 5). In this sense, our paper contributes to the postcolonial agenda of building decentered urban theory.

The concept of popular urbanization focuses on the actions of people involved in the construction and maintenance of their own houses and their neighborhoods. This 'popular' aspect refers to a wide range of actors producing urban space mostly without evident leadership or overarching ideology but with a shared interest in producing urban space for themselves as well as their community. These social groups can often be defined by categories such as kinship, friendship, origin, religion, or political affiliation. They appropriate and produce urban space through a wide spectrum of collective action, starting from the interaction of individuals to neighborhood coordination up to high-level collective mobilizations. In popular aspirations to produce and to preserve urban neighborhoods the spatial practices of people generate not only material outcomes, but also deep local knowledge. These daily practices and urban experiences result in 'other spaces', which have the potential to question hegemonic visions and strategies of the production of urban space. Popular urbanization is thus an urban strategy through which urban territories are produced, transformed and appropriated by the people.

In proposing the concept of popular urbanization, we don't intend to idealize collective efforts and projects, since they are also pervaded with self-interest and power hierarchies (Simone, 2014), but we suggest to shift the analytical perspective towards a dynamic understanding of the social production of urban space and to shed light on how these spaces emerge, how they transform over time, and particularly, how they differ from spaces produced through other related but distinct urbanization processes. We understand an urbanization process as an ensemble of socio-spatial transformations based on a specific set of involved agencies, spatial practices and social contradictions. Our approach emphasizes urbanization processes across space and time. This has two important consequences: First, it implies that urbanization processes change over time, and 
that they unfold differently in each place resulting in a variety of urban outcomes and temporal trajectories, pointing to different urban futures (see also Diener et al., 2015); popular urbanization is thus a revisable and open concept. Second, according to this basic understanding, an urban territory is usually formed by several distinct urbanization processes. Popular urbanization is thus a specific process that has to be comprehended in relation to the other urbanization processes that shape an urban territory. In our project, we identified several other related urbanization processes, such as 'mass housing urbanization' or 'plotting urbanism' (see below).

We developed the concept of popular urbanization through a collective comparative analysis of Lagos, Mexico City, Istanbul and Kolkata. ${ }^{1}$ This analysis is part of the research project 'Patterns and Pathways of Planetary Urbanization', which started in 2011 and analyzed various urbanization processes in eight large metropolitan territories: Tokyo, Hong Kong/Shenzhen/Dongguan, Kolkata, Istanbul, Lagos, Paris, Mexico City, and Los Angeles. The goal of this project is to contribute to the development of an enriched vocabulary of urbanization in order to allow a better understanding and wider discussion of the variety of urbanization processes that are shaping today's urban worlds. Building on a transdisciplinary approach, our team brings together the expertise of architects, sociologists, geographers, social and cultural anthropologists (for a broader introduction into methodology, theoretical base and research framework, see Schmid et al., 2018). This comparison is based on collaborative work, where the members of the team brought their disciplinary backgrounds and empirical research into a shared methodological framework, while allowing the evolving comparison to inform their own research. The fieldwork comprised various forms of fieldtrips and interviews with inhabitants and experts, new forms of qualitative mapping, and a careful engagement with a broad local scholarship including publications in different languages. As such, this paper relies on an abundant set of theoretical resources and empirical data, and particularly on fieldwork in Ecatepec, Ciudad Nezahualcóyotl, Valle de Chalco Solidaridad, Santo Domingo and Chimalhuacán in Mexico City (Streule, 2018; 2019); Badia and Ajegunle in Lagos (Sawyer, 2016); and Başıbüyük (Karaman; 2013; 2014), Zeytinburnu and Eyüp in Istanbul. ${ }^{2}$

How could we bring such a variety of experiences in different urban contexts into conversation with each other? How is it possible to compare seemingly incommensurable experiences from different places without losing their specific qualities and intrinsic characteristics? We found inspiration from a variety of comparative theoretical and empirical engagements with urban processes across space and time (c.f. Robinson, 2011, 2013, 2016; see also Schmid, 2014; Hart, 2016; Caldeira, 2017). In such a relational comparison '[...] elements of the past gain new meanings for the present, produce new futures for the past, and open up a space of action towards possible futures

\footnotetext{
${ }^{1}$ For reasons of length we don't present the case study of Kolkata in this article (see Schmid et al., 2018).

2 Space constraints don't allow us to present our findings in detail.
} 
from the present' (Robinson, 2013: 664). Consequently, we framed urbanization processes as the result of complex entangled histories of diverse agencies. Building on Lefebvre's three-dimensional theory of the production of space (Lefebvre, 1991 [1974]), we developed a multidimensional understanding of urbanization that highlights how social space is produced through material interaction, territorial regulation, and everyday experience. We can't go into the details of our theoretical considerations here, but the most important aspect of this approach is to conceive these three dimensions as linked to each other through dialectical relationships (see also Schmid, 2008; 2015). Additionally, our understanding of urbanization is based on the decentering perspective of planetary urbanization, which radically puts into question the 'urban boundary'. As a consequence, urban territories can't be apprehended as bounded units, but have to be explored as open configurations by analysing the interplay of various urbanisation processes that are shaping the territory (Brenner and Schmid, 2015, Schmid, 2018).

On the basis of this general analytical framework we followed a transductive approach (Lefebvre 1991 [1974]) that ties the empirical research directly into the theory production and allowed us to address the persisting tension 'between localized analyses of particular cities and their projection in the form of wider analyses of urban processes' (Robinson, 2013: 662). We therefore had no specific pre-given concepts as starting points for the comparison, but developed the concept of popular urbanization through the comparative procedure itself. For this purpose, we brought the findings from all the eight urban regions into conversation with each other through twelve intense week-long comparative workshops, which enabled us to actually think each urban territory through the other territories and to detect urban processes across the different contexts. While every place at a given time is of course a specific result of many concrete determinations and constellations, it is nevertheless possible to identify certain underlying structures and logics that draw different experiences into comparison with each other (see Schmid, 2015). This comparative procedure was neither meant to diminish the richness of the case studies, nor to reduce the specificities of the concrete urban situations. Rather, it was the goal of this comparison to complement the analysis of individual case studies with an additional layer of analysis in order to reveal certain common characteristics and general features, while generating concepts that are sufficiently open to account for continuous urban transformation and numerous variations of the process itself. As part of this iterative comparative procedure, we confronted our empirical findings with existing related conceptualizations helping to elaborate and further nuance the proposed concept of popular urbanization we discuss here.

In the following, we begin with a critical review of some important extant concepts that could be used for the analysis of popular urbanization, and focus particularly on the debate on urban informality, evaluating its limits as well as its critical and innovative re-appropriations. We then discuss the alternative concept of urbanización popular as defined by Latin American scholars, 
which proved to be particularly fruitful for our analysis. In a conceptual move, we decontextualize this concept to delineate our own definition of popular urbanization, based on our comparative study. Finally, we recontextualize the concept, applying it to the three case studies of Mexico City, Lagos and Istanbul. In the main part of the paper, we examine how in these three contexts people organize themselves to build, occupy and secure their housing, their neighborhoods and everyday spaces through intricate webs of negotiation with each other, as well as with landowners and state actors, enabling incremental gains in infrastructure, facilities, and tenure security. In the last section, we outline the main characteristics of popular urbanization to put these analytical insights of our comparative study into a wider conversation.

\section{Poverty of terms}

When we started with our comparative project, we soon found some striking similarities between urbanization processes in certain low-income neighborhoods of Mexico City, Istanbul, Lagos and Kolkata. We discerned a process that is based on self-organization and collectivity, includes aspects of informality, illegality, and social struggle, and develops incrementally by constant improvement of houses and neighborhoods. As we applied a range of extant concepts to this process, we were confronted with many ambiguities and shortcomings. 'Slum', one of the most common terms to delineate areas with poor living conditions, only describes a material form and does not encompass the dynamic aspect of urbanization. Furthermore, it has become synonymous with poverty and precarity, and its use has been roundly criticized for contributing to the marginalization of such spaces and obscuring the diversity of urban experiences (Rao, 2006; Gilbert, 2007; Huchzermeyer, 2011; Varley, 2013). We followed Roy's (2011) critique based on the position of subaltern urbanism, and sought to account for heterogeneous urbanisms that 'cannot be contained within the familiar metonymic categories of megacity or slum' (ibid.: 231). Similarly, the terms gecekondu or favela, as regional terms for Turkish and Brazilian experiences, share many of these pejorative characteristics, even if they also imply certain elements of the production process of such spaces. Gecekondu literally means 'landed/built overnight' and thus at least gives some indication on the starting point of the process. The Portuguese term favela can be traced back to the late $19^{\text {th }}$ century and basically means autoconstructed (Valladares, 2006). However, these terms as well as concepts like 'autoconstruction' and 'self-help housing' that refer to building one's own house with little or no professional help are highly context specific. While of particular importance in Mexico City and also observed in Istanbul, autoconstruction is not a defining characteristic in Lagos.

There is a range of other concepts, which don't express the specificity of the process we identified through our comparative research yet highlight certain important aspects of this process, and thus also informed our conceptualization. For instance, as will be discussed in the following sections in more detail, we draw substantially on the idea of 'incremental urbanism' (e.g. Turner, 1976; 
McFarlane, 2011; Dovey, 2014) to better understand the characteristic step by step building process of popular urbanization and thus to rethink the specific challenges this materialization of emergent dynamics holds for practitioners like planners or architects. In a similar way, 'occupancy urbanism' introduced by Benjamin (2008) helps to understand the complex relationship between inhabitants of popular settlements on the one hand, and state actors and large land developers on the other. In the case of India, Benjamin depicts this relationship as highly politicized forms of urbanisms and helps to unveil the entrenched everyday dynamics in multiple political spaces. Likewise, the concept of 'insurgent citizenship' proposed by Holston (2009) helps to address questions of illegality and land occupation through the lens of citizenship. He shows how new forms of democratic citizenship are emerging from urban peripheries of São Paulo, Brazil, and brings to the fore two important aspects we are discussing in detail in the following sections, that is territorial regulation as well as experiences of solidarity in everyday life. Caldeira (2017) recently proposed the concept of 'peripheral urbanization' to characterize 'southern urbanisms'. Developed as the result of a comparative procedure, and providing a multidimensional definition of urbanization, this concept grasps the production of space across different urban areas and brings together a wide range of experiences. This encompassing concept, which consists 'of a set of interrelated processes' (Caldeira, 2017: 4) addresses some similar questions as our own project. Therefore, we will discuss this concept in the final part of our paper.

Finally, we also engaged with the widely applied concept of 'urban informality'. Introduced in the 1970s and originally applied to designate the labor conditions of poor immigrants working in street markets and all sorts of precarious jobs, this concept has set the informal aspect against the experience of a highly regulated 'formal economy' that generated a regular and secure income. The term informal was soon extended beyond the field of labor to designate also the production of housing and finally even a certain way of life. However, as a scientific concept, and even more so as a tool for policymakers, planners, and state agencies, the concept of informality has long been facing widespread critique for its binary conception of formal versus informal, its lack of differentiation of the various ways in which informality emerges and develops, and its exclusive focus on only one aspect of the regulation of urbanization. Thus, these initial approaches were, as Kudva puts it, 'splintered in discursive realms' (2009: 1615), hampering a dynamic understanding of the different aspects of informality and their interrelationships. While some scholars questioned the formal/informal dichotomy and highlighted linkages and continuities between the informal and the formal (e.g. Papola, 1980), others emphasized that the understanding of urban informality should not be reduced to marginality, but rather seen as fully albeit unevenly integrated into society (e.g. Perlman, 2010). In recent years, postcolonial scholars radically reclaimed the concept of 'urban informality' from dualistic understandings in an attempt to disrupt hegemonic ways of thinking, knowing and doing by emphasizing diversity, plurality, complexity and fluidity, and called for attention to differentiations within informality (e.g. AlSayyad, 2004; Soliman, 2004; Roy 2005). 
Informality has thus been interpreted as a 'complex and shifting phenomenon' (Huchzermeyer, 2011: 75) with many different facets changing over time (Gilbert, 2007). It was seen as a 'complex continuum of legality and illegality', and even understood as an 'idiom of urbanization' (Roy, 2005; 2009). Some scholars analyzed the broad spectrum of actors involved in urban informality, including state actors, wealthy people and middle classes (e.g. McFarlane and Waibel, 2012), while others showed that informality is not only widespread but also capable of being organized and effective (e.g. Simone, 2004; Denning, 2010). Another important move was the political interpretation of certain instances of informality as acts of everyday resistance distinct from large scale mobilizations that got the most attention in these discussions so far (e.g. Castells, 1983; Benjamin, 2008; Fawaz, 2009; Kudva, 2009; Bayat, 2010).

These critical explorations, appropriations and revisions show that the concept of urban informality embraces a wide and complex set of aspects and processes. While postcolonial critiques help to understand internal differentiation, and while it remains a useful term that speaks across disciplines, the very reach and breadth of the concept of informality does not allow for a precise definition of an urbanization process. In our own research, we detected a number of clearly distinct urbanization processes, in which informality plays an important role (see e.g. the concept of 'plotting urbanism' discussed below). Furthermore, the concept of urban informality still remains largely one-dimensional, and highlights a certain form of the regulation of the urban process. It is unclear how other important aspects of the production of space, such as social composition (e.g. class, income level), the dominance of individualized or collective forms of social organization, or the degree to which the production of space is commodified or self-organized intersect with informality. Therefore, very different urban constellations can be subsumed under the term informality, such as collective squatting in Delhi (Datta, 2012) or the (partly illegal) individual construction of expensive mansions in Belgrade (Diener et al., 2012). For all these reasons, we propose to go beyond informality, to develop a more differentiated and nuanced understanding of urbanization and to conceptualize more specific urbanization processes.

\section{Urbanización popular: a new vantage point}

An important starting point for our new comparative conceptualization was the term urbanización popular, which is used in Mexico and in other parts of Latin America. This term seemed to be particularly useful for several reasons: First of all, it is directly linked to urbanization. The Spanish term urbanización has an active connotation: initially coined and defined by Catalan urban planner Cerdà in 1867, the term designates the production and extension of settlement areas, and can thus be used to indicate active production of new neighborhoods. Second, the term popular refers not only to the urban poor in general, but has also a strong class connotation and is used here particularly to designate those people who are involved in the process of urbanization. A literal 
translation of the term urbanización popular thus would be 'urbanization by the people'. This denotation comes very close to the content we sought to express, and we found the term a very valuable and inspiring basis for our comparative conceptualization. To make it useful for our analysis we first had to explore its definition in the Latin American context and then to revise and rebuild it by confronting it with our own comparative results. In the following, we look at the Latin American understanding of urbanization processes in general, and to Mexican scholars specifically, aiming to develop a broader understanding of the terms with which we can comprehend urbanización popular as a 'contradictory form of self-organization of a society', and thus also as a 'disposition of the subjects in search of survival and modes of articulation outside the hegemonic formal system' (García Canclini, 2013: 35). ${ }^{3}$

The concept urbanización popular has been widely used in Latin America since the late 1980s for the analysis of social dynamics in marginalized urban areas (e.g. Navarro and Moctezuma, 1989; Schteingart 1989; 1996; Azuela, 1993; Duhau, 1992; 1998; Duhau and Giglia, 2008; Vite and Rico, 2001; Moctezuma, 2012). It is, along with other concepts like 'informalización' or 'favelização', one of the most frequently used terms to designate the process of the self-production of neighborhoods by the inhabitants that plays such a paradigmatic role in Latin America (e.g. Connolly, 2009; 2013; Perlman, 2010; Salazar, 2012; Hernández \& Becerra, 2017). In early conceptualizations, the prevailing understanding of urbanización popular was very similar to a widespread definition of informality, as the following quote exemplifies:

A very large number of families solve their housing problem by acquiring land under irregular conditions and self-producing their habitat. This is what we call urbanización popular. This urbanization process takes place in the form of subdivisions and irregular land operations on the margins of the officially recognized urban area; in this way, the population has access to land at a lower price than on the regular market, but it also means lower material conditions (Duhau, 1992: 48).

Conventional definitions of the term urbanización popular echo to a certain extent the well-known debate between structuralist and functionalist approaches towards urban informality. In a historicalstructuralist perspective, dependency theory scholars discuss urbanización popular under the aspect of the reproduction of cheap labor and uneven capitalist development. In a legalisticfunctionalist perspective, developmentalist scholars emphasize the entrepreneurial activities of people through autoconstruction and the creation of informal jobs, and identify the state as the crucial regulatory actor (for a wider discussion of these different perspectives, see Rakowski, 1994; González, 2012). In contrast to those classic understandings, Neo-Marxist urban scholars Navarro and Moctezuma (1989) developed a more dynamic conceptualization of urbanización popular, which was inspired by Castells' $(1977$; 1983) concepts of 'collective consumption' and 'urban social movements'. Based on their empirical research in Mexico City, they outlined two specific

\footnotetext{
${ }^{3}$ All translations are by the authors.
} 
characteristics of urbanización popular: the institutionalized collective working day (faena) and the emerging urban social movements and their struggles for basic services and land titles (movimiento urbano popular). For both aspects, they argue, territorial relations are constitutive "since in the specific urban context [...] (the poor) are the ones who are able to organize themselves collectively in pursuit of their common interests [...]" (ibid.: 84). Despite such analytical efforts to further specify this concept, the established understanding of urbanización popular has faced continuing critiques for failing to address subjectivities, particularly from the perspective of cultural studies. Thus, Hiernaux and Lindón argue:

Until recently, urban studies have made few distinctions between the residents of peripheral areas. The concept of 'urbanización popular', which has been used to characterize the process of advancing towards peripheral urbanization by disadvantaged groups, does not offer enough clues to analyze the difference between groups, according to the ways of seeing the world, the culture and lifestyles in the periphery. It is from the rise of so-called 'urban cultural studies' that further distinction is made as to who are residents of the city in terms of their subjectivity ... (Hiernaux and Lindón, 2000: 21).

As this short discussion shows, the term urbanización popular is widely used in the Latin American context, and it meets many aspects that we want to address; it offers therefore a very useful starting point for our analysis. We were especially interested in the term 'popular' as it has a range of connotations in Spanish, especially referring to the people, and to social class. However, its wide and sometimes contradictory definitions that often make it almost synonymous to urban informality are blurring the concept of urbanización popular. Furthermore, to make it applicable to a wider range of examples, it has also to be decontextualized from the specific Latin American situation to which it is tied. In order to give this term a more precise meaning, we opted for a transposition and adopted the English translation 'popular urbanization' to indicate the distance between inherited understandings and definitions of the term and our new comparative conceptualization, at the same time explicitly acknowledging the roots of the term and the concept. Departing from this critical understanding of the concept, we further adapted and enriched it in the course of our comparison. In our definition, we maintain both the focus on urban social movements and the emphasis on collective work, but recognize the need for addressing subjectivities, as suggested in more recent Latin American debates. Moreover, as previously discussed, we strive to move beyond postcolonial critiques of the urban informality debate by stressing the multidimensional and dynamic understanding of urbanization processes. Thus, we focus particularly on the crucial role of everyday experiences and on the agency of subjects in their production of space. This theoretical perspective directs our attention also to aspirations of residents to claim urbanity and centrality, and thus the right to the city: 'Popular' designates for us the spatial practices of people to generate different urban experiences, and to potentially challenge the vision of hegemonic urban space by producing territories of resistance (see Zibechi, 2012; Schwarz and Streule, 2016; Streule and Schwarz, 2019). 


\section{Mexico City, Lagos, Istanbul: Different urban experiences in conversation}

The process of popular urbanization unfolds in different ways in the specific urban contexts of Mexico City, Lagos, and Istanbul. As will become evident in the following sections, it is a highly variegated process, which also has changed significantly within each urban area over the last decades. In the following, we apply the multi-dimensional understanding of urbanization derived from Lefebvre's three dimensions of space - the perceived, the conceived, and the lived. We adapted them for our comparative procedure in order to conceptualize urbanization as a threedimensional production process, thus structuring the comparison along questions of material transformations, territorial regulations and social experiences of everyday life (see Schmid et al., 2018).

The specificity of the concept of popular urbanization can only be fully understood on the basis of a relational conception of urbanization that analyses an urban territory as the result of the interplay of several distinct urbanization processes. Thus, in the course of our comparative project, we identified and defined two other urbanization processes that are related to but clearly distinct from popular urbanization: 'plotting urbanism' and 'mass housing urbanization' (Schmid et al., 2018). Plotting urbanism is a process in which an urban area is developed in a piecemeal way, plot by plot, whereby commodification and market mechanisms play a key role (see Karaman et al., 2020). Plotting urbanism shares many aspects with popular urbanization, such as informality, illegality and an incremental building process; however, it is dominated by commodification, and the mobilization and the collective effort of inhabitants are significantly weaker compared to popular urbanization. Mass housing urbanization, another related concept, entails strong state intervention, often in combination with powerful business interests put forward by private developers and financial institutions, and could be understood as an alternative and in many ways opposite model to popular urbanization (see Kockelkorn et al., 2019). Popular urbanization, then, stands out as a process that is not dominated by the state, like mass housing urbanization, and it is also not strongly determined by market mechanisms and commodification (even if these factors might play a certain role).

\section{Material transformations of urban territory}

Popular urbanization was the predominant process of urbanization in Mexico City as well as in Istanbul in the second half of the $20^{\text {th }}$ century. At the turn of the century, areas of popular urbanization constituted about $60 \%$ of the urban area of Mexico City (Connolly, 2009) and large parts of Istanbul. More recently however, urbanization changed dramatically in both places. Whereas in Istanbul hardly any new gecekondus are built anymore, popular urbanization still takes place in Mexico City, particularly in some peripheral areas (e.g. Hastings, 2008; Vega, 2015; Gilbert and de Jong, 2015; Streule, 2018). In contrast, popular urbanization never reached the same importance and scale in Lagos; it was always marginal and largely overshadowed by 
'plotting urbanism' as the dominant process of space production (Sawyer, 2014; 2016; Schmid et al., 2018).

How can we explain these different pathways of popular urbanization? All three case studies constitute large urban regions and major political, cultural, financial and commercial centers exerting strong influence beyond their regional hinterlands. They have all experienced strong migration for many decades, leading to massive population growth rates, which increased demand for housing dramatically. Whereas Turkey and Mexico, starting from the 1940s, followed a developmentalist model of industrialization that initially drew people to the main urban centers for manufacturing and services, Lagos attracted people mainly by its role as the political, cultural, and commercial center of Nigeria with one of the busiest ports in West Africa. Despite this massive urban growth, state led programs for housing production have been largely absent in Lagos, while in Mexico City and Istanbul they were mainly targeting groups who were already relatively affluent and/or had formal employment (Buğra, 1998: 308; Çoban, 2012: 86; Özdemir, 2011; Streule, 2017a). Thus, popular urbanization developed as an 'alternative pathway' enabling millions of people to get access to housing. Our analysis suggests that this shouldn't be seen as an isolated urban phenomenon but has to be situated in the context of the transformation of the entire urban territory and its complex interrelations of social, economic and political processes.

In all three cases a broad variety of agents are involved in the process of popular urbanization. In Mexico City, the first popular settlements were constructed by the migrants themselves as the broad body of literature on this topic highlight (for an overview, see Connolly, 2013). In an initial stage, groups of people invaded and settled on ejido lands based on previous agreements with the collective owners of the land, the ejidatarios. Middlemen (coyotes) were often playing a crucial part in getting the consent of these land owners, informally selling the former farm land plot by plot for a commission (Cymet, 1992; Jones and Ward, 1998; Gutman, 2000). The following first years, residents were dealing with many hardships and got organized to install and gradually improve urban services like electricity, water and drainage. They also cooperated to raise funding to construct schools, churches, or to get the streets paved (Azuela and Tomas, 1996; Schteingart, 1989; Hiernaux and Lindón, 2000). The self-built shelters fencing off the plot were initially very basic as well, often not more than one room built with flimsy materials such as wooden planks, tinplate or adobe bricks. Over the years, people improved their housing and living conditions investing in more durable materials and incrementally expanding their homes, adding more rooms and floors as in the classic and well researched example of Ciudad Nezahualcóyotl (Ribbeck et al, 2002; see also Bazant, 2003; Andrade Narváez, 2011). As we could observe, these self-help housing strategies are basically still the same today. Confronted with the notorious absence of a pro-active housing policy to provide sufficient affordable housing, the second and third generations of popular settlements are currently built on newly subdivided plots in remote areas of Mexico City 
such as the municipalities of Chimalhuacán, Chicoloapan or Nicolás Romero. During the last decades however, the close relationship between popular urbanization and rural-urban migration changed; today, relocation from older settlements and circular migration to and from the U.S. play a much more prominent role in this process (Streule, 2018). As the vast majority of Mexico City's inhabitants cannot afford or are not eligible to participate in the national mortgage finance system, they often rely on remittances from family members migrated to the U.S. as a major source of funding for construction materials and to pay the plot deposit (enganche) (Mendoza and Bartolo, 2012; Streule, 2018). Additionally, government related clientelist organizations - such as the wellknown mass organizations Antorcha Popular or the Frente Popular Francisco Villa - have also intervened aggressively in popular urbanization processes, orchestrating land occupation and land distribution at a large scale (Vega, 2015: 285). These organizations play a key role in todays' popular neighborhood improvement. Their main function, however, is to negotiate between different residents, land owners and state institutions. They are hierarchically structured organizations, having good contacts with local governments and mediate complex clientelistic deals to acquire urban equipment, public services or to regularize land titles for their members.

In Istanbul, we can observe a similar diversification of actors and modes of popular urbanization. Each neighborhood - and even different sections within a neighborhood - had its unique experiences depending on a variety of factors, most notably, the timing of establishing the settlement, the landownership status, the specific position within the wider urban region as well as the organization of relations with state officials. Nonetheless some broad contours can be identified. At the very initial stages of popular urbanization the dominant image was that of rural migrants who constructed their makeshift shacks on primarily public land (Şenyapılı, 1998; Keyder, 2005). As informal land markets developed popular urbanization acquired a more commercial character (Tekeli, 1992; Torlak, 2003: 66). By the 1980s mafia-like groups and religiouscommunitarian organizations were heavily involved in the parcelization and allocation of land (Işık and Pınarcıoğlu, 2001: 167-8; Pérouse, 2011: 62-3). The strategies adopted for the construction process also show a high variation even within a given urban area, such as self-building, hiring workers or mutual assistance within the community. Such strategies also transformed significantly over time. The first generation of popular settlements in Istanbul for example were often built overnight by the prospective residents themselves, an experience that is still contained in the term gecekondu. With increasing commercialization, small-scale construction teams led by foremen oversaw the whole process (Torlak, 2003: 66). At a certain moment, strongly commercialized private interests became more dominant at the expense of mobilizations by residents for housing and infrastructure provision. In our understanding, when commodification becomes dominant, the process of popular urbanization turns into plotting urbanism. 
Popular urbanization has not always been successful. Crucial for the persistence of the newly established neighborhoods is the extent to which they are able to 'take hold', and consolidate into less precarious settlements. In Istanbul and Mexico City, the majority of popular settlements acquired a robust character over time with decent infrastructure and sanitation. In contrast, Lagos' popular settlements have struggled to survive under very low tenure security and have maintained their makeshift appearance. For instance, large portions of the infamous Makoko settlement, currently the largest area of popular urbanization in Lagos (population estimates range from 40,000 to hundreds of thousands) have been demolished and rebuilt several times in the last decades. This settlement at a prominent central location on water in the Lagos lagoon is often used as iconic illustration for the 'slums of Lagos'. Maroko, an even larger settlement of 300,000 people was demolished in 1990, making land available for the private residential development of Lekki (see Agbola and Jinadu, 1997). Today, this area is one of the most expensive real estate assets in Lagos. As these examples show, there are very different pathways and many possible outcomes of popular urbanization, ranging from demolition to consolidation. In order to understand them as results of the same basic process, it is necessary to analyze the specific territorial regulations that underlie, enable and guide popular urbanization.

\section{Coping with territorial regulation}

The most crucial precondition for popular urbanization is first and foremost to get access to the land. Popular urbanization embraces many different routes to settling - such as squatting land, constructing on legally protected land, or buying illegally subdivided plots. In Mexico City, popular urbanization predominantly developed on collectively owned ejido and communal land. ${ }^{4}$ Here, landowners, and also real-estate promoters illegally subdivided land to sell it to newcomers (Schteingart, 1989; Azuela and Tomas, 1996; Jones and Ward, 1998). In contrast, people in Istanbul installed themselves primarily on public land, as the state was generally more tolerant of emerging settlements (Buğra, 1998: 309; Işık and Pınarcıoğlu, 2001: 115). At later stages, unofficially subdivided agricultural lands were increasingly used for informal housing provision (Yonder 1987; Tekeli, 1992: 64). Another way to access land is to make exposed and hostile locations such as flood-prone areas, steep slopes or canyons 'habitable' through some improvements; examples are landfilling with residual materials in the swampy land of Lagos' Ajegunle, or removing large amounts of lava rocks in Mexico City's Santo Domingo. According to the different land regimes, the territorial regulation of the three case studies differ profoundly. ${ }^{5}$ Property rights were relatively clearly defined in Istanbul (ownership by local and central state,

\footnotetext{
${ }^{4}$ Ejido is corporate private owned agricultural land, established by the Mexican Revolution, which until a constitutional reform in 1992 could not be sold legally and thus constituted the largest source of land for popular urbanization. Communal land is the collectively managed land of urban villages and belongs to the indigenous communities. Both, communal and ejido land are subject to the same legal rules (see Azuela, 1993; Cymet, 1992; Sambieda, 1996).

5 Land regulation policies in Istanbul and Mexico City have longstanding and well-studied trajectories (for Mexico City see e.g. Eckstein, 1977; Azuela, 1993; Schteingart, 1996; Salazar, 2012; and for Istanbul see Öncü 1988; Tekeli, 1992; Buğra 1998; Şenyapılı, 1998; Işık and Pınarcıoğlu, 2001; Demirtas-Milz, 2013). For Lagos, in contrast, research on land regulation is less well-established (e.g. Akinleye 2009; Sawyer, 2016).
} 
charitable foundations or private individuals) and in Mexico City (primarily ejido and communal land, and to a lesser extent private and state-owned land).

In contrast, territorial regulation in Lagos is far more complex because it is constituted by dual land systems simultaneously at work, leading to widespread confusion and insecurity over land and title (for a detailed analysis see Sawyer, 2016). The formal procedure for obtaining an official land title in Lagos is extremely bureaucratic, time-consuming and expensive. Additionally, people who seek to build a house in Lagos have to engage with traditional landowners; however, these transactions do not confer any security, but rather are necessary to settle who has a customary claim to the land. This means that a piece of land can easily have more than one claim of ownership with some validity, leading to frequent lengthy disputes (Aluko, 2012). One major outcome of this specific territorial regulation in Lagos is the individualization and commodification of urbanization leading to 'plotting urbanism'. People in areas of popular urbanization engage in similar agreements with traditional landowners to secure access to land, but in a crucial difference these agreements are usually limited in time or may be reneged upon by the landowners, who sometimes prohibit permanent structures from being built as they wait for the value of the land to increase (Aina, 1989). There is a long, familiar tradition of portraying neighborhoods of popular urbanization in Lagos as 'slums', with the full pejorative connotations of the term, to justify their forced eviction and demolition (Agbola and Jinadu, 1997). Put briefly, the Nigerian State - colonial, military and civilian - has acted time and again with seeming impunity against popular urbanization, usually in collusion with traditional landowners. Therefore, there has never been a chance for the neighborhoods to consolidate.

In contrast, Istanbul has had a form of territorial regulation that accommodated and retroactively regularized popular urbanization for decades. Numerous laws have been passed that formalized concessions to gecekondu dwellers known as gecekondu amnesties (gecekondu afları). ${ }^{6}$ In the very early stages gecekondus were widely regarded as a 'social disaster' encroaching upon the city proper (Şenyapılı, 1998: 308), and the immediate state response usually was their demolition (Torlak, 2003). From the early 1950s onwards in the context of rapid industrialization, gecekondu neighborhoods were increasingly tolerated and accommodated (Torlak, 2003; Şenyapılı, 2004). This stage is characterized by a tight and symbiotic relationship between factories and gecekondus, manifested in their geographic proximity to each other (Tekeli, 1992: 38; Esen, 2011: 469). With their tacit acceptance and formal recognition gecekondus became increasingly commodified (Torlak, 2003). In the aftermath of the military coup of 1980, tenure legalization policies were put in place, which authorized the vertical redevelopment of plots on which gecekondus were built (Ekinci, 1998). This resulted in the significant densification and

\footnotetext{
${ }^{6}$ For a comprehensive review of these legislations see (Torlak, 2003; Tercan, 2018).
} 
commercialization of erstwhile gecekondu neighborhoods. The commercial and monetary aspect became more dominant at this stage, so we have studied this transformation under the rubric of 'plotting urbanism'. Today, some areas still retain their gecekondu character due to legal complications or the lack of a political initiative to implement regularization policies. There are also some more recently constructed areas in the 1990s, which never attained legal status. Since the mid-2000s these remnants of popular urbanization have been targeted for removal by various schemes of redevelopment most notably with the involvement of state agencies constructing mass housing such as TOKI and KIPTAS (Lovering and Türkmen, 2011, Karaman, 2013; Türkün, 2014). The history of popular urbanization in Istanbul thus reveals a visible shift in the basic urban policy. For decades the state failed to develop proactive policies to address the housing needs of lowincome citizens in the public or private sector. Instead it used ad hoc measures to legalize and regulate them with successive gecekondu amnesties. This situation facilitated the rapid growth of informal land markets, particularly favoring those who were able to participate in the earlier rounds of land occupation (Işık and Pınarcıoğlu, 2001), and the emergence of plotting urbanism as a dominant process in Istanbul. With the urban policy shift in the 2000s towards urban renewal, gecekondus ceased to be an effective option for the urban poor as a means of upwards social mobility (cf. Esen, 2011: 486).

In quite a similar way, but with a different outcome, the pathway of popular urbanization in Mexico City illustrates the conflicting but also entangled relation between government and a large majority of the urban society (e.g. Azuela and Tomas, 1996). In an effort to adapt urban policies to the ongoing urbanization processes, the state tolerated popular urbanization, but also sought to control and regulate the process. When the Federal District (the state that governs the central area of Mexico City, recently renamed CDMX) implemented restrictions on illegal subdivisions and trade of ejido lands in 1954, this strongly pushed the process of popular urbanization out towards adjacent federal states (Azuela, 1993; Duhau, 1998). In this context, new popular settlements for millions of inhabitants spread out to what were then remote, but are today relatively central locations, such as Ciudad Nezahualcóyotl or Ecatepec (Bassols and Espinosa, 2011). However, this policy did not stop popular urbanization in central areas, but gave rise to a new strategy of land invasion called paracaidismo (parachuting urbanization), in which people were occupying land overnight (e.g. Vega, 1996; Gutman, 2000). Similar to the case of Istanbul, regularization of popular urbanization seemed to be the most promising governmental approach to neighborhoods of popular urbanization, at the same time providing a strong foothold for the then ruling party PRI. ${ }^{7}$ Until 1970, approximately ten to fifteen million inhabitants of Mexico City purchased a plot on ejido land to build their homes. These transactions proceeded usually without overwriting regular land titles and

7 Federal and local policy relating to popular urbanization still is embedded in a complex patron-client system and embraces a selective and patronizing strategy of regularization and eviction (e.g. Varley, 2002; Guarneros-Meza, 2009; Wigle, 2014; Vega, 2015). 
accordingly were situated beyond state control, albeit with the implicit involvement of local authorities (Cymet, 1992; Jones and Ward, 1998; Hiernaux and Lindón, 2000; Lombard, 2016; Connolly and Wigle, 2017). A far-reaching shift of territorial regulation in Mexico City accompanied the neoliberal land reform in 1992, when collective use rights of ejido land were declared as individual rights and the sale of ejido land was eventually legalized. With this reform, over three million hectares of land in the urban periphery of Mexico City became potentially available for market speculation (Sambieda, 1996; Jones and Ward, 1998; Salazar, 2014). The state explicitly declared agricultural ejido land as a reserve zone for potential urbanization, leading to the massive increase of commercial mass housing urbanization in the peripheries of Mexico City, the so-called Mega Conjuntos Habitacionales. However, popular urbanization did not decline as much as in Istanbul, but remains one of the important processes of the production of urban territories in Mexico City (e.g. Hastings, 2008; Connolly, 2009; Vega, 2015: 275; Gilbert and de Jong, 2015; Streule, 2018). These examples of territorial regulation show clearly the important role of state strategies embedded in wider political constellations and power relations, and influenced by contradictory goals and interests in facilitating, shaping and bringing an end to popular urbanization.

\section{Experiences of solidarity in everyday life}

Popular urbanization can't be fully understood without illuminating the crucial role of social mobilizations, collective experiences and learning processes in shaping these developments, and thus without taking into consideration the question of 'lived experiences' in the production of space. The very beginnings of popular urbanization in Istanbul were strongly dependent on social networks, based on kinship, or a shared place of origin in the countryside (hemşehrilik), not only for finding and creating livelihoods, and a place and materials to construct a gecekondu, but also in providing the main platforms of everyday socialization (Gunes-Ayata, 1991). As migrants faced many challenges in their new neighborhoods, they also had to develop local networks based on their shared experiences and daily struggles. These were largely based on patronage relationships relying on charismatic and commercially driven leadership able to negotiate with state actors (Erder, 1996; White, 2002: 104-7; Keyder, 2005). Additionally, in the second half of the 1970s, gecekondu mobilizations in many neighborhoods took a radical turn mainly in reaction to the exploitative practices of emerging mafia-like groups cashing in on the commercialization of land (Tekeli, 1992: 91-92; Aslan, 2004). Squatters' struggle to claim space outside the formal system aligned with socialist groups' objective of 'creating cores outside the control of formal institutions in practically all realms of social life' (Aslan, 2004: 81). However, these radical inclinations were significantly undermined first by the 1980s military coup and then by the tenure legalization policies that followed (Erman, 2004: 987). Today, regional associations still remain major centers of solidarity and socialization, particularly in late-stage gecekondu areas, which are now targets for urban renewal schemes (Pérouse, 2011: 84; Karaman, 2014). 
In Mexico City, relatively hierarchical neighborhood organizations guided by charismatic leaders perform mostly routine functions to solve daily problems and needs. In these organizations, a specific participatory and collective practice has developed, characterized by general meetings and consensual decision-making. Framed as 'urban self-management', as many scholars have argued, such strategies in Mexico City do not mean simply 'managing the misery', but could be understood as an alternative urban strategy of self-organized administration and collective control of urban space (see e.g. Schteingart, 1991; Coulomb, 1992; Moctezuma, 2001, 2012; Ortiz and Zarate, 2002; Streule, 2017b; Díaz-Parra, 2019). Whereas these organizations fight mainly for land tenure, basic urban infrastructure such as electricity and water supply, as well as access to health care and education, people themselves also take a longer-term perspective: a house is most commonly seen as a patrimonio, a space of belonging that is constantly improved and adapted to new needs, such as accommodating new family members or starting small businesses (see Gilbert, 1999; 2002; Calderón, 2012; Ward, 2012; Grajeda, 2015).

In Lagos, social organization in popular settlements mostly emerges through various memberbased religious, ethnic, hometown, trade associations or patronage networks, that are not however necessarily locally organized. These can perform vital functions in problem solving and conflict neutralization or as a basis for savings groups (esusu). There are also neighborhood vigilante groups that provide security. Since the 1990s, 'Community Development Associations' have been formed to provide an interface between traditional power structures, the local and state governmental actors and the people (Abegunde, 2009). However, the elected representatives of these associations are sometimes co-opted by landowning families, and/or governmental actors, and can even end up working against the communities. There is a huge variation in how well a community is organized, and this can depend largely on how well the residents of a street or building get on with one another, and whether private connections to influential people can be activated (Sawyer, 2016). In our study, the Lagos case provides an important reference point for expanding an understanding of the 'popular' that does not rely on notions of mass mobilization or a strongly organized collectivity.

The way residents are organized to promote, implement and sustain popular urbanization therefore covers a broad spectrum between individualism and collectivity. In Istanbul, many gecekondu settlements emerged largely as the cumulated outcome of individual decisions, without any overarching plan. However, in improving their living conditions, gecekondu residents often used the tradition of imece, ${ }^{8}$ in which they collectively provide the necessary labor and resources for

\footnotetext{
8 Imece is reminiscent of the aforementioned collective workday faena in Mexico City, which is applied to meet daily needs of the inhabitants - a basic element of popular urbanization relying on collective work engaging in practices of commoning (Leitner and Sheppard, 2018; Petropoulou, 2018).
} 
infrastructural improvements on a voluntary basis (Duyar-Kienast, 2005:42, based on the case of Ankara; Esen, 2011: 468). In cases where the parcelization and selling of land was highly commercialized, there was some semblance of coordination at the overall settlement scale. This becomes clear in the overall layouts. Classic gecekondu neighborhoods on state owned lands are marked by an organic street pattern that more or less aligns with the topography, whereas gecekondus on illegal subdivisions of agricultural lands are parcelized with standardized street width so as to maximize developable lots (Işık and Pınarcıoğlu, 2001: 162). Another form of land occupation is based on formally organized grassroots initiatives. In her study of a gecekondu neighborhood in Ankara, Duyar-Kienast, (2005:124-30) provides an example of an informal housing cooperative, in which the land occupation, parcelization and gecekondu construction were carried out in a highly organized (yet from the point of the state illegal) fashion under the leadership of a community leader.

In Lagos by contrast, people are more likely to procure power supply and water individually (through small diesel generators and buying water in sachets or jerry cans), although this relies on highly organized and competitive private suppliers. As residents are not able to consolidate and improve their houses and environment over time, living conditions are often extremely poor and unhealthy and present significant daily challenges. Forms of collectivity that are not necessarily based in the neighborhood, such as youth groups, hometown groups, religious groups and trading groups (Osaghae, 1999; Akinola, 2007) provide many sources of support, for instance, savings and loans to low-income earners in a country where access to banking services is not inclusive. As discussed previously, there is a long tradition of unanswered brutality and injustice by the national state against the poorest residents in terms of forced evictions, slum clearances, market clearances and confiscation or destruction of property. A few organizations fight forced eviction; however, in the absence of an effective formal justice system, and very little political accountability, residents seem to have given up on formal channels of justice (Amnesty International, 2018). Nevertheless, recent protests against evictions in Badia in 2014 and Otodo Gbame in 2017 have achieved small but significant and unprecedented gains, such as modest monetary compensation, pressure from international organizations and an acknowledgment from the state of its actions.

Popular urbanization is strongly shaped by collective social processes. In the struggles for claiming land, getting access to basic services and producing their own neighborhoods inhabitants generate shared experiences and specific knowledge. In this contradictory process, popular urbanization may also result in 'other spaces' with specific urban qualities (Streule and Schmid, 2014; Streule, 2017b). Thus, various venues, shops and street markets have emerged in neighborhoods like Valle de Chalco Solidaridad or Chimalhuacán in Mexico City that do not only offer a livelihood for many people living in the neighborhood, but also contribute to the improvement of everyday life and the creation of centralities in these seemingly 'peripheral' places. The production of urban 
qualities is particularly visible in more established and consolidated popular neighborhoods such as Nezahualcóyotl with its wide range of facilities (universities, schools, health centers, hotels, markets, sport facilities, etc.). In Istanbul, the remaining low density gecekondus near the center provide unique qualities beyond infrastructure, public transportation, and basic amenities. A neighborhood like Başıbüyük, located on top of a breezy hill, commanding great views of the sea, and retaining its village-like character is a quite livable place. In presenting alternative forms of social and spatial organization, the inhabitants and the users of such neighborhoods are also articulating claims to difference and non-commodified forms of urbanity. In this sense, popular urbanization has the potential to challenge hegemonic practices of the production of space, which are mainly based on market mechanisms and/or state strategies (see e.g. also Fawaz, 2009; Kudva, 2009; Huchzermeyer, 2011; Zibechi, 2012; Keenan, 2015; Díaz-Parra, 2019).

\section{Outlining Popular Urbanization}

In her recent paper on 'peripheral urbanization', Caldeira (2017) identifies some crucial characteristics of urbanization in the 'global south'. In comparing 'dissimilar' cases in Istanbul, Santiago de Chile and São Paulo, she discusses very different modalities of urbanization, including autoconstructed settlements as well as state-controlled housing programs that she brings together under the term 'peripheral urbanization'. While she observes a great heterogeneity and dynamism, she stresses the everyday efforts of residents to improve their neighborhoods, the transversal logics in which the various actors engage with formal institutions and the distinctive modes of political engagement they are generating. Certainly, these aspects were present in our case studies of Mexico City, Istanbul, and Lagos. However, our comparative project proceeded in a complementary direction: instead of searching for overall similarities across different kinds of settlements, we sought to identify specific urbanization processes and to reveal their distinct inner logics. Instead of widening, we therefore narrowed down the scope of our concepts. In doing so, we identified systematic differences between various urbanization processes that we consider crucial, namely marketization and commodification, the role of state agencies, and collective activities and experiences. Accordingly, we propose three different urbanization processes that are dominated by clearly different aspects but all might fit under the conceptual umbrella of peripheral urbanization: while 'plotting urbanism' has a strong orientation towards market mechanisms, and mass housing urbanization is strongly initiated and determined by state actors, popular urbanization is mainly based on self-organization, mobilization and collectivity. To the extent that this set of three concepts is the result of our comparative research it is strongly influenced by our selection of case studies. It is therefore an open list and the concepts should be seen as revisable.

How, then, might we define popular urbanization? As has become visible, this process unfolds in diverse ways according to concrete urban contexts and thus shows a great variety of spatial outcomes and temporal trajectories, even in the same city. Nevertheless, it is possible and useful 
to identify some main characteristics of popular urbanization as a specific urbanization process and thus to distinguish it from other closely related urbanization processes. The definition of popular urbanization starts with the decisive feature of people creating their own neighborhoods. This can be understood as a strength, and not defined as a lack or a deficiency. Popular urbanization is thus a form of the production of urban space that is based primarily on the collective initiative of the people. This distinguishes it from mass housing urbanization that is strongly determined by initiatives of state agencies, and from plotting urbanism dominated by commodification and market mechanisms.

In our comparison, we first focused on the material aspect of the production of space, the physical transformation of the urban territory and the interactions that are necessary to produce new settlements. This included the analysis of migration processes and the different agents involved: migrants and settlers creating their own urban spaces, embedded in various social, cultural, political and religious networks, as well as organizations that support and enable the construction and improvement of buildings and neighborhoods. While popular urbanization is thus a process in and through which an urban territory is continuously produced, transformed and appropriated by its inhabitants and users as the main protagonists of the urbanization process, state actors and state strategies always play an important role, and market mechanisms are involved to a lesser or higher degree. But the specificity of popular urbanization consists in the collective process of the production of space by the initiative, engagement and labor of the people, often accompanied by strong social and political mobilization.

These basic characteristics are shaped to a considerable degree by the concrete urban conditions and social relations that underlie urbanization at particular places and times. In Mexico City, Lagos and Istanbul, the starting point of popular urbanization was massive immigration of low-income people from rural areas and the resulting need for affordable housing. As state strategies for the construction of large-scale public housing were lacking, popular urbanization offered an alternative option for the production of new neighborhoods. However, in these three urban territories popular urbanization has played very different roles. In Mexico City and Istanbul, it became the dominant urbanization process for decades, during which large urban areas were constructed, stabilized and consolidated. The massive and fast urban growth of these two metropolises was in fact to a large extent based on popular urbanization. In contrast, popular urbanization never played a major role in Lagos, because its dominant urbanization model relied mainly on a much more individualized and market-oriented form of urban development that we conceptualized as plotting urbanism. The analysis of the pathways of popular urbanization also sheds light on the long-term character and the different trajectories such processes might take: from the eradication of the popular settlements through slum clearance policies, such as in Lagos, to a certain consolidation as in Mexico City, or formalization and marketization as in Istanbul. However, as discussed above, the importance of 
this urbanization process for Mexico City has been diminished in recent years, while in Istanbul the gecekondu is largely a historical phenomenon.

To understand these different trajectories it is necessary to look at the different ways state agencies intervene in the process. While the state is not a key actor in the process of popular urbanization, it can nevertheless only fully unfold if there is a 'tacit agreement' between parts of the population and powerful state actors. In all three cases, the state intervened in various ways in the process of popular urbanization, through mediations, negotiations, active support, silent tolerance, the development and implementation of competing strategies, or open repression and demolition. Struggles between the inhabitants and state actors are therefore a constitutive element of popular urbanization. These struggles are sometimes open and explosive, but mostly occur immanently and within the prevailing system of power, for example in the form of cooptation and corruption. Thus, informality and illegality have to be understood as constitutive aspects of the processes of territorial regulation, which characterize popular urbanization (see also Roy, 2005; Schmid, 2015: 301).

In all three examples collective action and everyday struggles for maintaining and improving the neighborhoods and the collective fights for access to the land, for getting land tenure, and for basic infrastructure generate experiences and processes of learning that shape popular urbanization in specific ways. While in Lagos collective struggles against precarity predominate, popular urbanization in Mexico City is based on home ownership and the importance of the house as a legacy for the (extended) family. The autoconstructed house that is constantly adapted according to the needs of the family members thus also gains a strong symbolic value. It is interesting that market mechanisms didn't evolve within popular urbanization in Mexico City: rooms usually are not let out to tenants, and houses are rarely offered for sale. In Istanbul however, market mechanisms were present relatively early. With the consolidation of those neighborhoods, processes of commodification intensified. This explains to a certain degree the different pathways of popular urbanization. While popular urbanization in Istanbul mostly turned into plotting urbanism, it still subsists as a distinctive process in Mexico City. In Lagos, popular urbanization has faced violent repression and demolition for a long time, leading to precarity and inhibiting any form of consolidation.

These different pathways of popular urbanization can only be fully understood if contextualized in the ensemble of urbanization processes that shape the metropolitan territory beyond single neighborhoods. Because of the lack of social housing in Mexico City and in Istanbul, there was almost no other option available to accommodate the massive influx of migrants. However, as our analysis reveals, there were also certain decisive conditions that enabled popular urbanization, first of all the availability of land (mainly public or collectively owned land) that allowed the construction 
of the first 'illegal' settlements. Another important condition was the state strategy to tolerate and even negotiate the construction and consolidation of these settlements. The presence of collective networks, a certain degree of political organization, and specific collective traditions were other necessary conditions for the success of popular urbanization. In Lagos however, none of these conditions were present, and thus plotting urbanism, as a strongly individualized and market oriented strategy, became the dominant model of urban development, while popular urbanization was only an option in very specific, often precarious situations for relatively small areas. In contrast, in Mexico City neighborhoods consolidated and developed highly appreciated urban qualities. In Istanbul however, this consolidation process turned gradually into plotting urbanism. Finally, in both Mexico City and Istanbul the state intervened and implemented a new urban strategy at the beginning of the $21^{\text {st }}$ century: state-led mass housing urbanization, which involved the neoliberalization, financialization, and commodification of urban development through developers and financial institutions (see e.g. Hastings, 2008; Karaman, 2013; Gilbert and de Jong, 2015; Erman, 2016). Popular urbanization has therefore to be seen as a specific historical and geographical phenomenon: it is an urbanization process that under certain conditions might emerge and flourish, but might also be fundamentally transformed or even disappear. Thus it is important to understand the historical moments that generate, enable or hinder popular urbanization as the result of the entanglements of numerous actors and urban constellations.

What are the specific advantages of popular urbanization? While born out of specific and often precarious circumstances, it can also advance utopian moments of collectivity, engagement, and mutual self-help. It provides some very practical advantages: it enables a high degree of flexibility and adaptability, allowing for the incremental evolution of the settlement responding to the needs and requirements of the inhabitants, adaptation to changing socioeconomic situations, and offering opportunities for social inclusion. These qualities of popular urbanization are further highlighted by contrasting them with current state-led programs of mass housing urbanization that have resulted in various failures and massive urban sprawl in Mexico City and in dense and inflexible housing estates in Istanbul.

The concept of popular urbanization might be able to inform policy making and to develop credible and plausible alternatives to current state housing policies. However, while this kind of urban development remains relevant in many places around the globe, it is currently devalued by discourses about 'slum free cities', by large scale urban renewal programs and by various forms of state- and developer-led housing (see e.g. Huchzermeyer, 2011; Leitner and Sheppard, 2018). Against these tendencies, renewed models of popular urbanization could offer more inclusive, collective and radical perspectives for the production of urban neighborhoods. In this sense, the term 'popular urbanization' becomes programmatic in highlighting the positive and progressive potentials inherent to this specific urbanization process: urbanization with and by the people. 


\section{References}

Abegunde, A.A. (2009) The role of community based organisations in economic development in Nigeria. International NGO Journal 4.5, 236-52.

Agbola, T. and A.M. Jinadu (1997) Forced eviction and forced relocation in Nigeria. The experience of those evicted from Maroko in 1990. Environment and Urbanization 9.2, $271-$ 88.

Aina, T.A. (1989) 'Many routes enter the market place': housing submarkets for the urban poor in Metropolitan Lagos, Nigeria. Environment and Urbanization 1.2, 38-49.

Akinleye, R.T. (2009) Contesting for space in an urban centre: The Omo Onile Syndrome in Lagos. In Locatelli, F. and P. Nugent (eds.) African cities: Competing claims on urban spaces, Brill, Leiden; Boston.

Akinola, S. R. (2007) Coping with infrastructural deprivation through collective action among rural people in Nigeria. Nordic Journal of African Studies 16.1, 30-46.

AISayyad, N. (2004) Urban informality as a 'new' way of life. In A. Roy and N. AISayyad (eds.), Urban Informality. Lexington Books, Oxford.

Aluko, O. (2012) The effects of land use act on sustainable housing provision in Nigeria. Journal of Sustainable Development 5.1, 114-22.

Amnesty International (2018) Left with nowhere to go: Stories of survivors of forced evictions in Nigeria's megacity. AFR 44/9290/2018. Amnesty International, Abuja.

Andrade Narváez, J. (2011) Viviendas en proceso. [Homes in process]. In J. Andrade Narváez and E. Carballo Curz (eds.), La vivienda popular en México. Retos para el siglo XXI [Popular housing in Mexico. Challenges fo the 21st century], UAM, Mexico City.

Aslan, Ş. (2004) 1 Mayıs Mahallesi: 1980 Öncesi Toplumsal Mücadeleler ve Kent [Mayday Neighborhood: Pre-1980 Social struggles and the city]. Iletisim Yayınları, Istanbul.

Azuela, A. (ed.) (1993) La urbanización popular y el orden jurídico en América Latina [Popular urbanization and the legal order in Latin America]. UNAM, Mexico City.

Azuela, A. and F. Tomas (eds.) (1996) Acceso de los pobres al suelo urbano [Access of the poor to urban land]. Colmex; IIS-PUEC UNAM, Mexico City.

Bassols, M. and M. Espinosa (2011) Construcción social del espacio urbano. Ecatepec y Nezahualcóyotl. Dos gigantes del oriente [Social construction of urban space. Ecatepec and Nezahualcóyotl. Two giants in the east]. Polis 7.2, 181-212.

Bayat, A. (2010) Life as politics: how ordinary people change the Middle East. Amsterdam University Press, Amsterdam.

Bazant, J. S. (2003) Viviendas progresivas. Construcción de vivienda por familias de bajos ingresos [Progressive homes: Housing construction for low-income families]. Trillas, Mexico City.

Benjamin, S. (2008) Occupancy urbanism. Radicalizing politics and economy beyond policy and programs. International Journal of Urban and Regional Research 32.3, 719-29.

Buğra, A. (1998) The Immoral Economy of Housing in Turkey. International Journal of Urban and Regional Research 22.2, 303-17 
Caldeira, T. (2017) Peripheral Urbanization: Autoconstruction, transversal logics, and politics in cities of the global south. Environment and Planning D: Society and Space 35.1, 3-20.

Calderón, J. (2012) La agenda pendiente de la formalización de la propiedad en el Perú [The pending agenda of the formalization of property in Peru]. In C. E. Salazar (ed.), Irregular. Suelo y mercado en América Latina [Irregular. Land and market in Latin America], Colmex, Mexico City.

Castells, M. (1977) The urban question. MIT Press, Cambridge.

Castells, M. (1983) The city and the grassroots. University of California Press, Berkeley.

Çoban, A. N. (2012) Cumhuriyetin ilanından günümüze konut politikası. [Housing policy from the declaration of the republic until present] Ankara University SBF Journal, 67.3, 75-108

Connolly, P. (2009) Observing the evolution of irregular settlements. Mexico City's colonias populares, 1990 to 2005. International Development Planning Review 31.1, 1-35.

Connolly, P. (2013) La ciudad y el hábitat popular. Paradigma Latinoamericano [The city and the popular hábitat. A Latin American paradigm]. In B. Ramírez and E. Pradilla (eds.), Teorías sobre la ciudad en América Latina [Theories about the city in Latin America], UAM, Mexico City.

Connolly, P. and J. Wigle (2017) (Re)constructing informality and 'doing regularization' in the conservation zone of Mexico City. Planning Theory and Practice 18.2, 183-201.

Coulomb, R. (ed.) (1992) Pobreza urbana, autogestión y política [Urban poverty, self-management and politics]. CENVI, Mexico City.

Cymet, D. (1992) From ejido to metropolis, another path. An evaluation on ejido property rights and informal land development in Mexico City. Peter Lang Publishing, New York \& Bern.

Datta, A. (2012) The illegal city. Space, law and gender in a Delhi squatter settlement. Routledge, London.

Demirtas-Milz, N. (2013) The regime of informality in neoliberal times in Turkey. The case of the Kadifekale urban transformation project. International Journal of Urban and Regional Research 37.2, 689-714.

Denning, M. (2010) Wageless life. New Left Review 66, 79-97.

Díaz-Parra, I. (2019) The squatters' and tenants' movement in Buenos Aires. A vindication of centrality and the self-managed production of space. In Yip, NM, MA Martínez López, X. Sun (eds.) Contested cities and urban activism. Palgrave Macmillan, Singapore.

Diener R., Meili, M., Topalovic, M. and C. Müller Inderbitzin (eds.) (2012) Belgrade. Formal / informal. Scheidegger \& Spiess, Zurich.

Diener R., et al. (2015) The Inevitable Specificity of Cities. ETH Studio Basel/Lars Müller Publishers, Zurich.

Dovey, K. (2014) Incremental urbanism: the emergence of informal settlements. In T. Haas and K. Olsson (eds.), Emergent urbanism. Ashgate, Farnham \& Burlington. 
Duhau, E. (1992) La régularisation de l'habitat au Mexique [The regulation of habitat in Mexico]. Annales de la recherche urbaine 51, 48-55.

Duhau, E. (1998) Hábitat popular y política urbana [Popular habitat and urban policy]. Miguel Ángel Porrúa \& UAM-A, Mexico City.

Duhau, E. and A. Giglia (2008) Las reglas del desorden. Habitar la metrópoli [The rules of disorder. Inhabit the metropolis]. Siglo XXI, Mexico City.

Duyar-Kienast, U. (2005) The formation of gecekondu settlements in Turkey. The case of Ankara. LIT, Münster.

Eckstein, S. (1977) The poverty of revolution. The state and urban poor in Mexico. Princeton University Press, Princeton.

Ekinci, O. (1998) Kaçak yapılaşma ve arazi spekülasyonu. [Unauthorised construction and land speculation] In Y. Sey and D. Özkan (eds), 75 Yılda değişen kent ve mimarlık [Changing Architecture and the City during 75 years], Tarih Vakfı, Istanbul.

Erder, S. (1996) Istanbul'a bir kent kondu: Ümraniye. [A town landed on Istanbul: Ümraniye] lletisim Publishing, Istanbul.

Erman, T. (2001) The politics of squatter (gecekondu) studies in Turkey: the changing representations of rural migrants in the academic discourse. Urban Studies 38.7, 9831002.

Erman, T. (2016) Formalization by the state, re-informalization by the people: A gecekondu transformation housing estate as site of multiple discrepancies. International Journal of Urban and Regional Research 40.2, 425-40.

Esen O. (2011) İstanbul'dan öğrenmek [Learning from Istanbul] In Y. Köse and A. Dağlı (eds) Istanbul: Imparatorluk Başkentinden Megakente [Istanbul: From imperial capital to megacity]. Kitap Publishing, İstanbul.

Fawaz, M. (2009) Neoliberal urbanity and the right to the city. A view from Beirut's periphery. Development and Change 40.5, 827-52.

García Canclini, N. (2013) Zur Metamorphose der lateinamerikanischen Stadtanthropologie. Ein Gespräch [On the metamorphosis of Latin American urban anthropology. A conversation]. In A. Huffschmid and K. Wildner (eds.), Stadtforschung aus Lateinamerika [Urban studies from Latin America]. Transcript, Bielefeld.

Gilbert, A. (1999) A home is for ever? Residential mobility and homeownership in self-help settlements. Environment and Planning A 31.6: 1073-91.

Gilbert, A. (2007) The return of the slum. Does language matter? International Journal of Urban and Regional Research 31.4, 697-713.

Gilbert, J. and F. de Jong (2015) Entanglements of periphery and informality in Mexico City. International Journal of Urban and Regional Research 39.3, 518-32.

González, J. R. (2012) La urbanización popular en la literatura: un esbozo de teoría [Popular Urbanization in literature: an outline of theory]. Realidades. Revista de la Facultad de Trabajo Social y Desarrollo Humano 2.2, 80-96. 
Guarneros-Meza, V. (2009) Mexican urban governance. How old and new institutions coexist and interact. International Journal of Urban and Regional Research 33.2, 483-501.

Gutmann, M. C. (2000) La invasión de Santo Domingo [The invasion of Santo Domingo]. In ibid. Ser hombre de verdad en la ciudad de México. Ni macho ni mandilón [Being a real man in Mexico city. Neither macho nor mandilon], Colmex, Mexico City.

Grajeda, E. (2015) On housing, inheritance and succession among pioneer squatters and self builders. A Mexican case study. In C. Klaufus and A. Ouweneel (eds.), Housing and belonging in Latin America. Berghahn, New York \& Oxford.

Gunes-Ayata, A. (1991) Gecekondularda kimlik sorunu, dayanışma örüntüleri ve hemşehrilik.[The question of identity, solidarity patterns and fellow-townsmenship in gecekondus] Toplum ve Bilim 51/52, 89-101.

Hart, G. (2016) Relational comparison revisited: Marxist postcolonial geographies in practice. Progress in Human Geography OnlineFirst.

Hastings, I. (2008) El problema cualitativo en la producción del hábitat popular en la Ciudad de México [The qualitative problem in the production of the popular habitat in Mexico City]. Informes de la Construcción 60.511, 25-40.

Hernández, F. And A. Becerra (2017) Informal and formal development in cities of Latin America. Cambridge Scholars Publishing, Newcastle.

Hiernaux, D. and A. Lindón (2000) Una aproximación a la construcción social del lugar en la periferia de la ciudad de México [An approach to the social construction of place in the periphery of Mexico City]. In Hiernaux, D., Lindón, A. and J. Noyola (eds.), El Valle de Chalco. La construcción social de un territorio emergente [The Chalco Valley. The social construction of an emerging territory]. Colegio Mexiquense, $\mathrm{H}$. Ayuntamiento del Valle de Chalco Solidaridad Dirección de Cultura, Zinacantepec Mexico.

Holston, J. (2009) Insurgent citizenship. Disjunctions of democracy and modernity in Brazil. Princeton University Press, Princeton.

Huchzermeyer, M. (2011) Cities with, slums'. From informal settlement eradication to a right to the city in Africa. UCT Press, Cape Town.

Işık, O. and M.M. Pınarcıoğlu (2001) Nöbetleşe Yoksulluk. Gecekondulaşma ve Kent Yoksulları: Sultanbeyli Örneği.[Rotating poverty. Gecekondu formations and the urban poor: the Example of Sultanbeyli] İletişim, İstanbul.

Jones, G. and P. M. Ward (1998) Privatizing the commons. Reforming the ejido and urban development in Mexico. International Journal of Urban and Regional Research 22.1, 76-93.

Karaman, O. (2013) Urban Renewal in Istanbul: Reconfigured Spaces, Robotic Lives. International Journal of Urban and Regional Research, 37.2, 715-33.

Karaman, O. (2014) Resisting urban renewal in Istanbul. Urban Geography, 35.2, 290-310.

Karaman, O., Sawyer, L., Schmid, C., and K. P. Wong (2020) Plot by plot: plotting urbanism as an ordinary process of urbanisation. Antipode, 52.4, 1122-1151.

Keenan, S. (2015) Subversive Property: Law and the production of spaces of belonging. Routledge, New York. 
Keyder, C. (2005) Globalization and social exclusion in Istanbul. International Journal of Urban and Regional Research 29.1, 124-34.

Kockelkorn, A., Schmid, C., Streule, M. and K. P. Wong (2019) Mass housing urbanization. Working paper, Department of Architecture, ETH Zürich.

Kudva, N. (2009) The everyday and the episodic. The spatial and political impacts of urban informality. Environment and Planning A 41.7, 1614-28.

Lefebvre, H. (1991 [1974]) The Production of Space. Cambridge: Blackwell.

Lombard, M. (2016) Land conflict in peri-urban areas: Exploring the effects of land reform on informal settlement in Mexico. Urban Studies 53.13, 2700-20.

Lovering, J. and H. Türkmen (2011). Bulldozer neo-liberalism in Istanbul: The state-led construction of property markets, and the displacement of the urban poor. International Planning Studies 16.1, 73-96.

McFarlane C (2011) Learning the City: Knowledge and Translocal Assemblage. Wiley-Blackwell, Chichester.

McFarlane, C. and M. Waibel (eds.) (2012) Urban informalities. Ashgate, Farnham \& Burlington.

Moctezuma, P. (2001) Community-based organization and participatory planning in south-east Mexico City. Environment \& Urbanization 13.2, 117-33.

Moctezuma, P. (2012) La Chispa. Orígenes del movimiento urbano popular en el valle de México [The spark. The origins of the popular urban movement in the valley of Mexico]. Delegación Iztapalapa \& Para Leer en Libertad A.C., Mexico City.

Navarro, B. and P. Moctezuma (1989) La urbanización popular en la ciudad de México [Popular Urbanization in Mexico City]. IIE-UNAM \& Editorial Nuestro Tiempo, S. A., Mexico City.

Ortiz Flores, E. And L. Zarate (eds.) Vivitos y coleando. 40 años trabajando por el hábitat popular de América Latina [Alive and kicking. 40 years working for the popular habitat of Latin America]. UAM, Mexico City.

Osaghae, E. E. (1999) Exiting from the state in Nigeria. Journal of African Political Science 4.1, 83-98.

Özdemir, D. (2011) The role of the public sector in the provision of housing supply in Turkey 19502009. International Journal of Urban and Regional Research 35.6, 1099-117.

Papola, T.S. (1980) Informal sector: concept and policy. Economic and Political Weekly 15.18, 817-24.

Perlman, J. (2010) Favela. Four decades of living on the edge in Rio de Janeiro. Oxford University Press, New York.

Pérouse, J.F. (2011) İstanbul'la yüzleşme denemeleri, çeperler, hareketlilik ve kentsel bellek [Essays on confronting Istanbul, peripheries, mobility and urban memory]. letisim Publications, Istanbul. 
Petropoulou, C. (2018) Social resistances and the creation of another way of thinking in the peripheral 'self-constructed popular neighborhoods': Examples from Mexico, Argentina, and Bolivia. Urban Science 2.1, Art.27.

Rakowski, C. A. (ed.) (1994) Contrapunto: the informal sector debate in Latin America. State University of New York Press, Albany.

Rao, V. (2006) Slum as theory. The south/Asian city and globalization. International Journal of Urban and Regional Research 30.1, 225-32.

Ribbeck, E., Padilla, S. and F. Dhaman (2002) Die informelle Moderne: spontanes Bauen in Mexiko-Stadt [Informal modernism: spontaneous building in Mexico City]. awf-Verlag, Heidelberg.

Robinson, J. (2011) Cities in a world of cities. The comparative gesture. International Journal of Urban and Regional Research 35.1, 1-23.

Robinson, J. (2013) The urban now. Theorising cities beyond the new. European Journal of Cultural Studies 16.6, 659-77.

Robinson, J. (2016) Thinking cities through elsewhere: Comparative tactics for a more global urban studies. Progress in Human Geography 40.1: 3-29.

Roy, A. (2005) Urban Informality. Journal of the American Planning Association 71.2, 147-58.

Roy, A. (2009) Why India cannot plan its cities: informality, insurgence and the idiom of urbanization. Planning Theory 8.1, 76-87.

Roy, A. (2011) Slumdog cities. Rethinking subaltern urbanism. International Journal of Urban and Regional Research 35.2, 223-38.

Salazar, C. E. (ed.) (2012) Irregular. Suelo y mercado en América Latina [Irregular. Land and market in Latin America]. Colmex, Mexico City.

Salazar, C. E. (2014) ,El puño invisible' de la privatización [The invisible fist of privatization]. Territorios 30, 69-90.

Sawyer, L. (2014) Piecemeal urbanisation at the peripheries of Lagos. African Studies 73.2, 27189.

Sawyer, L. (2016) Plotting: The prevalent but undertheorized residential areas of Lagos. PhD thesis, ETH Zurich.

Schmid, C. (2008) Henri Lefebvre's theory of the production of space: Towards a threedimensional dialectic. In K. Goonewardena et al. (eds.), Space, Difference, Everyday Life: Reading Henri Lefebvre. Routledge, London.

Schmid, C. (2014) Patterns and pathways of global urbanization: Towards comparative analysis. In N. Brenner (ed.), Implosions / Explosions: Towards a Study of Planetary Urbanization. Jovis, Berlin.

Schmid, C. (2015) Specificity and urbanization. A theoretical outlook. In R. Diener et al. (eds.), The inevitable specificity of cities, Lars Müller Publishers, Zurich.

Schmid, C. (2018) Journeys through planetary urbanization: decentering perspectives on the urban. Environment and Planning D, Society and Space 36.3, 591-610. 
Schmid, C., Karaman, O., Hanakata, N., Kallenberger, P., Kockelkorn, A., Sawyer, L., Streule, M. and K. P. Wong (2018) Towards a new vocabulary of urbanisation processes. A comparative approach. Urban Studies 55.1, 19-52.

Schteingart, M. (1989) Los productores del espacio habitable. Estado, empresa y sociedad en la ciudad de México [The producers of living space. State, company and society in Mexico City]. COLMEX, Mexico City.

Schteingart, M. (1991) Autogestión urbana y derechos ciudadanos [Urban self-management and citizen rights]. Nueva Sociedad 114, 133-42.

Schteingart, M. (1996) Urbanización popular y regularización de la tenencia de la tierra. Dos casos en municipios conurbados del estado de México [Popular Urbanization and regularization of land tenure]. In F. Tomas and A. Azuela (eds.), El acceso de los pobres al suelo urbano [Access of the poor to urban land], CEMCA-UNAM, Mexico City.

Schwarz A. and M. Streule (2016) A transposition of territory: Decolonized perspectives in current urban research. International Journal for Urban and Regional Research 40.5, 1000-16.

Şenyapılı, T. (1998) Cumhuriyet'in 75. yılı, gecekondunun 50. Yılı [75th anniversary of the republic, 50th anniversary of the gecekondu]. In Y. Sey and D. Özkan (eds), 75 Yılda değişen kent ve mimarlık. [Changing Architecture and the City during 75 years] Tarih Vakfı, Istanbul.

Şenyapılı, T. (2004) Charting the 'Voyage' of Squatter Housing in Urban Spatial 'Quadruped.' European Journal of Turkish Studies, Thematic Issue N¹ - Gecekondu, URL: http://www.ejts.org/document142.html (online)

Leitner, H and Sheppard, E. (2018) From Kampungs to Condos? Contested accumulations through displacement in Jakarta. Environment and Planning A: Economy and Space, 50.2, 437-56.

Siembieda, W. (1996) Looking for a place to live: transforming the urban ejido. Bulletin of Latin American Research 15.3, 371-85.

Simone, A. M. (2004) People as infrastructure. Intersecting fragments in Johannesburg. Public Culture 16.3, 407-29.

Simone, A. M. (2014) Jakarta: Drawing the city near. University of Minnesota Press, Minneapolis.

Soliman, A. (2004) Tilting at sphinxes. Locating urban informality in Egyptian cities. In A. Roy and N. AlSayyad (eds.), Urban Informality. Lexington Books, Lanham.

Streule, M. (2017a) Tracing the developmentalist regime of productivity. Nation, urban space, and workers' habitat in Mexico City, 1940s-1970s. In P.-P. Bänziger and M. Suter (eds.), Histories of productivity. Genealogical perspectives on the body and modern economy, Routledge, New York.

Streule, M. (2017b) Post- und dekoloniale Perspektiven der Stadtforschung: Eine andere Lesart der Urbanización Popular von Mexiko-Stadt [Post- and decolonial perspectives in urban studies: A different reading of popular urbanization in Mexico City]. In R. Steger et al. (eds.), subalternativen. Postkoloniale Kritik und dekolonialer Widerstand in Lateinamerika [subalternatives. Postcolonial critique and decolonial resistance in Latin America], edition assemblage, Münster. 
Streule, M. (2018) Ethnografie urbaner Territorien. Metropolitane Urbanisierungsprozesse von Mexiko-Stadt [Ethnography of urban territories. Metropolitan urbanization processes in Mexico City]. Raumproduktionen: Theorie und gesellschaftliche Praxis Band 32. Westfälisches Dampfboot, Münster.

Streule, M. (2019) Doing mobile ethnography: Grounded, situated and comparative. Urban Studies online first.

Streule, M. and A. Schwarz (2019) "Not all spaces are territories": creating other possible urban worlds in and from Latin America - an interview with Raúl Zibechi. Geographica Helvetica 74, 105-11.

Streule, M. and C. Schmid (2014) Popular urbanization. A comparative concept in urban studies. Yearbook ETH Zürich, gta Verlag, Zurich.

Tekeli, İ. (1992) Development of urban administration and planning in the formation of Istanbul metropolitan area. In T. Şenyapılı et al. (eds.), Development of the Istanbul Metropolitan Area and low cost housing, Turkish Social Science Association, Istanbul.

Tercan, B. (2018) 1948'den Bugüne İmar Afları [Zoning Amnesties from 1948 to today] Mimarlık, 403, Sept.-Oct., 20-26

Torlak, S. E. (2003) Gecekondulasmanin Gelisimi, imar aflari ve islah imar planlari. Cagdas Yerel Yonetimler, 12.1, 64-73

Turner J. (1976) Housing by people: towards autonomy in building environments. Pantheon Books, New York.

Türkün, A. (ed) (2014) Mülk, Mahal, İnsan: İstanbul'da Kentsel Dönüşüm. [Property, Locality, People: Urban renewal in Istanbul] Istanbul Bilgi University Press, Istanbul

Valladares, L. (2006) La favela d'un siècle à l'autre: mythe d'origine, discours scientifiques et représentations virtuelles [The favela from one century to another: myth of origin, scientific discourse and virtual representations]. Maison des sciences de l'homme, Paris.

Varley, A. (2002) Privat or public. Debating the meaning of tenure legalization. International Journal of Urban and Regional Research 26.3, 449-61.

Varley, A. (2013) Postcolonialising informality? Environment and Planning D: Society and Space $31.1,4-22$.

Vega, A. (1996) La regularización de la tenencia de la tierra en Santo Domingo de los Reyes (Distrito Federal) [The regularization of land tenure in Santo Domingo de los Reyes (Federal District)]. In F. Tomas and A. Azuela (eds.), El acceso de los pobres al suelo urbano [Access of the poor to urban land], CEMCA-UNAM, Mexico City.

Vega, A. (2015) La urbanización en la periferia de la ciudad de México [Urbanization in the periphery of Mexico City]. In A. Ziccardi and A. González (eds.), Habitabilidad y política de vivienda en México [Habitability and housing policy in Mexico], UNAM, Mexico City.

Vite, M. A. and R. Rico (2001) Qué solos están los pobres. Neoliberalismo y urbanización popular en la Zona Metropolitana de la Ciudad de México [How lonely are the poor. Neoliberalism and popular Urbanization in the metropolitan area of Mexico City]. Plaza y Valdés, Mexico City. 
Ward, P. M. (2012) 'A patrimony for the children'. Low-income homeownership and housing (im)mobility in Latin American cities. Annals of the Association of American Geographers 102.6, 1489-510.

White, J. B. (2002) Islamist mobilization in Turkey: a study in vernacular politics. University of Washington Press, Seattle.

Wigle, J. (2014) The 'graying' of 'green' zones: Spatial governance and irregular settlement in Xochimilco, Mexico City. International Journal of Urban and Regional Research 38.2, 57389.

Yonder, A. (1987) Informal land and housing markets. The case of Istanbul, Turkey. Journal of the American Planning Association, 53.2, 213-219.

Zibechi, R. (2012) Territories in resistance. A cartography of Latin American social movements. AK Press, Oakland. 